\title{
RAMB: BIMENSAL, QUALIS A NACIONAL E QUALIS C INTERNACIONAL
}

No final do ano, chegou ao Brasil um dos mais antigos registros da humanidade: os manuscritos do Mar Morto. Com mais de 2.000 anos de história, os textos são provavelmente contemporâneos à época em que Jesus Cristo viveu. Foram encontrados por acaso, em cavernas, na região do Mar Morto, uma das mais áridas da Terra. Pelas características climáticas estáveis e baixa umidade, garantidas pelas centenas de metros sob 0 nível do oceano, os manuscritos encontram-se em bom estado de conservação. A sua interpretação vem revelando ao mundo aspectos até então desconhecidos das tribos que se isolaram naquele território aparentemente por dissidência política ou religiosa.

A análise detalhada dos textos por especialistas no assunto poderá, em mais alguns anos, "reviver" idéias e padrões culturais de quem viveu cerca de 80 gerações antes de nós.

É irresistível realizar uma comparação deste panorama com os dias de hoje. A evolução tecnológica permitiu a utilização do registro de informações até mesmo por quem não é capaz de escrever. Por outro lado, o processo de digitalização nos fez prescindir das cavernas e de condições climáticas especiais para a preservação.
Em pouco tempo, por necessidade, compulsão ou simples curiosidade, os registros foram multiplicados, exigindo o desenvolvimento de ferramentas de pesquisa, identificação e classificação.

$\mathrm{Na}$ ciência e na medicina, em particular, a ferramenta teve de ser constantemente aprimorada para garantir maior eficiência e responder à demanda: - Ministério da Saúde da França publicou recentemente uma norma segundo a qual novos conhecimentos para o diagnóstico e tratamento de crianças autistas devem ser imediatamente incorporados à prática, em virtude do grande impacto das inter venções precoces sobre esta condição. Experiência semelhante ocorreu há alguns anos com a AIDS, quando foi dispensada a obrigatoriedade de estudos de FASE 3 para a comercialização de novos fármacos para a doença.

Ferramentas com MEDLINE e SCIELO, que usam a internet como veículo, tornaram-se muito populares e facilitaram a sistematização do conhecimento científico. Hoje, o autor que submete um artigo à RAMB pode fazê-lo eletronicamente no site www.ramb.org.br Também pela internet pode acompanhar o processo de avaliação e os pareceres dos revisores e editores. Uma vez aceito, o trabalho científico é disponibilizado no site da revista, que agora tornou-se bimestral. Ao acessar a RAMB e "baixar" o artigo, o leitor está aumentando o fator de impacto da revista, em um procedimento equivalente àquele da citação na seção de referências. Ao escolher um título adequado, o autor poderá cativar a atenção do leitor que recebe, por e-mail, os E-TOCS, a resenha do conteúdo da RAMB. Estes aprimoramentos valeram à RAMB a classificação Qualis Nacional $A$ e Qualis Internacional C, segundo os critérios da CAPES, órgão que regulamenta a pós-graduação brasileira.

O aumento progressivo do número de trabalho enviados e do interesse dos leitores identificado pela maio freqüência de acessos ao site da revista na internet indicou aos editores a necessidade de tornar a RAMB bimestral.

Que a visita dos manuscritos signifique um sinal de prosperidade para a RAMB e para a pesquisa brasileira em Medicina. Não mais em cavernas e talvez em registros holográficos, que os pesquisadores das gerações futuras possam compreender o complexo e difícil período em que estamos vivendo.

Bruno Caramell 
O arquivo disponível sofreu correções conforme ERRATA publicada no Volume 51 Número 3 da revista. 